\title{
Alienability: rejoinder to Kuflik
}

\author{
Walter Block \\ College of Business Administration, Loyola University New Orleans, \\ New Orleans, Louisiana, USA
}

\begin{abstract}
Purpose - The purpose of writing this paper is to defend the doctrine of commodification, or alienability: that there are no exceptions to the principle that all things that are owned may be legally sold.

Design/methodology/approach - The approach of this paper is to consider arguments to the contrary, mainly those, in this case, furnished by Kuflik, and then to refute these arguments.

Findings - The conclusion of this paper is that socialism, the view that purchases and sales, markets, free enterprise, is unjustified, is mistaken. Non-alienability is part and parcel of the critique of markets. To the extent it is countered, markets are strengthened.

Research limitations/implications - Future research would probe more deeply into anti-market arguments.

Practical implications - The practical implications is that the law should legalize markets in body parts, and, more radically, should recognize voluntary slave contracts.

Originality/value - This is virtually an entirely original paper, in that there are only a very few publications that defend complete alienability, such as does this one.
\end{abstract}

Keywords Legal principles, Selling, Right to buy, Trade, Philosophical concepts

Paper type Conceptual paper

\section{Introduction}

Buying, selling, renting, borrowing, lending - in a word - transferring property from one person to another is part and parcel of an economically integrated geographical area. If a widespread and inclusive European common market is to succeed to the extent hoped for by many of its advocates, a necessary precondition is full economic integration. Since this latter requires the legalization of full commercial interaction between and among the citizens of all member states, it cannot be denied that the freedom to "barter and truck" must be accorded them.

There is a debate with regard to inalienability taking place in the academic literature. [See Barnett (1986, 1998), Calabresi and Melamed (1972), Epstein (1985), Feinberg (1978), Kant (1930), Kinsella (1998-1999), Kuflik (1984, 1986), Locke (1960), McConnell (1984, 1996), Meyers (1981), Mill (1975[1859]), Radin (1987), Rose-Ackerman (1985), and Rousseau (1968)]. It is a bit one-sided, with most commentators maintaining that total and complete alienability, the right to buy and sell all property and personal attributes and characteristics, is impossible, or unwarranted, or unjust[1]. This is not per se a European issue; its importance cannot be confined to that continent; and, further, the debate over alienability is more of theoretical than practical interest. Nevertheless, it is also true that complete and total free trade, in all conceivable goods and services, whether foreign or domestic, is certainly of great importance to all members of the community. It is in this sense that the present philosophically oriented paper on the economics of the law will be of particular interest to the European law and economics community, at present; ultimately, however, this is an issue for all of mankind.

\subsection{Inalienability}

What is inalienability? Here is Rose-Ackerman's (1985, p. 931) definition: "Inalienability can be defined as any restriction on the transferability, ownership or use of an

Alienability: rejoinder to Kuflik




$\mathrm{H}$

23,3

118

entitlement." And according to Wilson and Daly (1992, p. 289): "Full proprietary entitlements include the right to sell, exchange, or otherwise dispose of one's property, to modify it without interference, and to demand redress for the theft or damage of it."

Thus, those who favor alienability favor laissez faire capitalism in political economy, since this system allows for complete economic freedom, including the right to buy and sell anything that is owned. This must be done on a mutually agreeable basis, but it allows for markets in such things as human organs for transplant, and even for indentured servitude for life, e.g. voluntary slavery. In contrast, those who advocate the inalienability thesis maintain that markets must be limited as to price, quality, etc.[2], and, in many cases, prohibited outright.

The present essay takes to task one supporter of the inalienability thesis, Professor Kuflik, and criticizes two of his articles on this subject.

\section{The inalienability of autonomy}

Kuflik (1984, p. 271) starts off this debate with a seeming clarion call for inalienability:

... no agreement by which a person places himself wholly and irrevocably at the disposition of someone else's will is valid and binding ... nobody can reasonably obligate himself not to function as a morally autonomous agent.

This appears eminently reasonable at the outset. However, it is possible to concoct a scenario where just such a contract is and ought to be considered "valid and binding." It will call into question the axiomatic status accorded by Kuflik to being "a morally autonomous agent."

My child is dying of a disease. The cure is readily available, but costs $\$ 1$ million. A poor man, I don't have anywhere near this amount of money, nor am I able to borrow it. You, a rich man, have long wanted to have me for your slave, to do your bidding without question, to have me in your power to such an extent that I am no longer "a morally autonomous agent."

The choice is before me: give up my child, or my moral autonomy. I choose to save my child's life. If Kuflik had his way, I could not have this option. For in his view, this agreement is not "valid and binding." If not, then the rich man will not pay the $\$ 1$ million, and my child will die.

Clearly, however, it is possible to alienate moral autonomy. If it were not even logically possible, why would we need a law to prohibit it? Why would we need an author such as Kuflik to deny its validity and bindingness? In contrast, a contract to sell a square circle is indeed invalid and non-binding. But no one feels the necessity to make a point of this. My claim is that Kuflik protests too much: if it is necessary for him to insist that such contracts cannot be binding, then they can. For what, then, is he objecting to[3]?

Kuflik (1984, p. 272) maintains that

To be "autonomous" is (literally) to be self-legislating or self regulating. This strongly suggests that what matters, from the standpoint of autonomy, are the principles by which a person lives. A person who determines his actions in accordance with principles he has mindlessly borrowed from others is not self regulating. . .

But this sounds like 99 and 44/100 per cent of humanity[4]. Most people do not think for themselves, at least regarding areas not in their realm of expertise. Moreover, "self legislating," if strictly interpreted, would involve total absence of government, or anarchy. This sounds like our author has bitten off more than he may want to chew 
[on this see McGee (1991, 1992), Spooner (1966 [1870]), Rothbard (1965, 1970, 1977a,b, 1978, 1998 [1982]), Hoppe (1989, 1993), De Jasay (1985), Benson (1990), and Barnett (1998)].

Presumably what is wrong with voluntary slavery is that it involves the sale of the will. But if people are not morally autonomous in the first instance, its sale must necessarily be of little moment. The point is, most people are already in the position of the reflective man who sells his will; namely, they do not "function as a critically reflective moral agent” (Kuflik, 1984, p. 272, no. 2).

Kuflik (1984, p. 273) himself admits that"... the morally reflective person is prepared to acknowledge that in certain cases someone else may be in a better position to gather morally relevant information.... But if this is so, what happened to being "self regulating"? Kuflik attempts to recoup with the claim that benefiting from assistance in this regard is irrelevant; the true test is whether a man is "able to justify, on morally rational grounds, the direction he has taken" (1984, p. 273). I suggest that this applies at best to philosophy professors and professional ethicists, and perhaps to their graduate students, who comprise, probably, less than $1 / 10$ of 1 per cent of the population as a whole. As a criterion for the average man, this is surely idiosyncratic and irrational. Surely a better determinant of whether a person is moral is his actions, not whether or not he can engage in meta ethics.

Kuflik (1984, p. 274) asks “... what would it mean to alienate one's autonomy?” and answers: "to alienate autonomy is to bind oneself to obey someone else, regardless of one's own critically reflective moral judgment." But this sounds like the behavior pattern of every sincerely religious person, to say nothing of the average man in the street.

\section{Kuflik's reply}

In an attempt to clarify his thesis, our author now offers four explications. They are as follows.

\subsection{Normative, not psychological}

To say that autonomy is inalienable is to make a normative, not a psychological claim. The question is not whether it is possible to think of oneself as having given up one's autonomy and to carry on accordingly, but whether it is morally appropriate to do so (Kuflik, 1984, p. 275).

But this is a veritable smoking gun: here is Kuflik's admission that it is possible to give up one's autonomy[5]. In his own view, we now see, this can be done; but it is immoral. Why is it morally unjustified to cede moral autonomy to someone else? At first glance, this would not appear to contradict any libertarian tenet, for libertarianism concerns itself not with morality or immorality, but rather with what the law should be. If we interpret Kuflik as being concerned only with morality, not with the propriety of legislation, then there is no conflict. On the other hand, if he takes the position that not only is alienability immoral, but that the law should reflect this by banning alienability, then there is indeed an incompatibility between the two philosophical perspectives.

\subsection{Alienation vs forfeiture}

Kuflik (1984, p. 275) addresses the issue of alienation vs forfeiture as follows:

To say that autonomy cannot be alienated is not to imply that in special circumstances it cannot be forfeited. A person may lose through misconduct what it would be wrong for him to transfer or relinquish through consent or agreement. 
$\mathrm{H}$

23,3

120
But this is more than passing curious. Let us take Kuflik at his word, despite his demurrals: autonomy cannot and should not be alienated. Why? Because, if this is done, the person ceases to be a moral agent[6]. But now along comes forfeiture, which, it would appear, justifies the seizure of moral autonomy. This is difficult to understand. If moral autonomy is so important that it cannot be voluntarily alienated, how can Kuflik assent to its seizure due to forfeiture? Logical consistency would imply he would oppose any such act. On the other hand, if moral autonomy is not all that important, such that it is justified to take it away in cases of forfeiture, then why is it so important when it comes to invalidating the voluntary slave contract? Kuflik, it would appear, wishes to have this both ways, and he cannot.

Consider now the objection to my thesis that autonomy abdication involves a logical contradiction. One implication of this is that it would prohibit voluntary guardianship for old people who agreed to it. And this goes as well for guardianship of children or the mentally ill[7]. Guardianship is in effect similar to turning yourself into a bullet, or a missile, to be used solely at the discretion of the guardian. If he is unscrupulous (e.g. Dickens' Fagin), this would lead to the logical contradiction claimed by Barnett (1986)[8]: you must both heed your guardian (based on contract) and not heed him (when he orders you to do something which is rights violative[9]).

\subsection{Compulsion or duress}

What about "compulsion or duress"? According to Kuflik (1984, p. 275), "To stay that autonomy cannot be alienated is not to deny that under compulsion or duress a person may be excused for acceding to demands..." This is acceptable; surely, the law must distinguish between voluntary choice and compulsion. But with this statement our author is in effect conceding that autonomy can be alienated; what else is he offering to excuse or more lightly penalize actions "that would not be worthy of his free rational acceptance" (Kuflik, 1984, p. 275) but for the fact that autonomy was breached, due to the threat?

\subsection{Guardianship}

States Kuflik (1984, p. 275): “. . . to say that autonomy cannot be alienated is not to deny that one human being can be legitimately subject to the guardianship of another."

However, guardianship is the taking away of autonomy from the ward. In the case of newborns, autonomy is seized without protest, since, almost by definition, a baby cannot coherently demur. But for older children, e.g. those equaling or exceeding the age of two year olds who have learned to say the word "no," and for those on the verge of senility, guardianship often occurs against the will of the person protected.

In contrast, the voluntary alienability associated with sale or gift can never occur in the teeth of opposition by the alienee, by definition. If autonomy were alienated against the will of the ward, then it could not possibly be voluntary alienability. Notice, too, the implication of the Kuflik philosophy. Guardianship which sometimes involves coercion is legitimate (e.g. against[10] children, the mentally handicapped, the elderly), while alienability which can never involve coercion (e.g. voluntary slavery) is not. This is less than fully convincing, at least for those who value consent of the party losing autonomy.

\section{Abdication}

\section{In Kuflik's (1984, p. 276) view,}

... suppose a person agrees to do what someone else tells him to do. If in making the agreement he agrees never to deploy his own critically reflective moral judgment, then... he has clearly abdicated ... his autonomy. 
This is as clear a denial of Kuflik's (1984, p. 275) statement “... autonomy cannot be alienated..." as can be imagined. When a writer contradicts himself, one page later, it is difficult to understand his point.

He again makes this same point (Kuflik, 1984, p. 276):

If someone were to reach, in advance, a morally reasonable decision to obey someone else regardless of his own critically reflective moral judgment, then he would be autonomously abdicating his autonomy.

About this, two remarks will suffice. First, let us hear no more from Kuflik about the impossibility of abdicating autonomy. Clearly, according to him, it can be done. Second, if we stipulate that God is a person, then it would appear that all sincerely religious people are autonomy abdicators. For they all, without exception, place their one critically reflective moral judgment second to those of God. Indeed, it is almost fair to state that the fully believing thesis has no critically reflective judgment apart from God's will, to abdicate from in the first place[11].

Kuflik (1984, p. 278) cites Rousseau, (1968, p. 60): “... to renounce freedom" is "to renounce one's humanity, one's rights as a man and equally one's duties." Having established that one can renounce freedom, and that there may be good and sufficient reason for doing so (to save your child's life), this otherwise ringing call loses a bit of power. In any case, "renouncing" freedom in this was is also an exercise of it. What better way to utilize your freedom than by saving the life of your child?

When Kuflik decided against a career in the National Football League, that sport lost what probably would have been an inspired broken field runner, for Kuflik (1984, pp. 280-1) has reversed field once again: “... because it is impossible to fulfill and autonomy -abdicating agreement, it is morally impermissible to make it." But we have cited this author himself to the effect that it is possible to fulfill an autonomyabdicating agreement[12]. Another difficulty: if it were really "impossible to fulfill and autonomy-abdicating agreement," it would not be "morally impermissible to make it." Rather, it would be meaningless. For example, it really is impossible to fulfill a square circle selling agreement. This is because there are no square circles; it is impossible for there to be any. But suppose, this notwithstanding, I make a contract with you to buy or sell one of them. Would this agreement be, of all things, "immoral"? Not at all. Instead, it would be an incomprehensible bit of gibberish.

$\operatorname{Kuflik}(1984$, p. 281)

... a measure of "mind control" can be attained through psychosurgery, brainwashing techniques, mind altering drugs, and the like. Someone could agree to have another person employ such devices to whatever ends the latter had chosen. In this way, he would not merely be promising obedience to the will of another; he would be taking effective steps to ensure compliance.

True. No truer words were ever penned on this subject[13]. But what is this but yet another reiteration of his concession that it is indeed possible for a person to alienate his autonomy?

In Rousseau's (1968, p. 54) paternalistic view: no autonomy abdicator "could be in his right mind." Kuflik tellingly replies to this bit of nonsense:

The agent who agrees to become someone else's complete and permanent slave need not have his own welfare in mind at all; the concession he seeks in return might be benefit that is to be bestowed upon loved ones or the promotion of a worthy cause.

We all applaud when the mother hen saves her chicks from the forest fire by shielding them with her own body in an act of suicide (she could have safely escaped on

\section{Alienability: rejoinder to Kuflik}


$\mathrm{H}$

23,3

122

her own, leaving her progeny to be burned). But this goes for humans as well as hens. It is difficult to reconcile such a sentiment with the prohibition of alienation through suicide, however.

\section{Philosophers}

\subsection{Kant}

Kuflik (1984, pp. 282-283) criticizes Kant's (1970, sec. 49, p. 153) "No one can enter by contract into such a state of dependence and thus cease to be a person; for only as a person is he able to make a contract." Kuflik's reply:

... the argument falters on a temporal equivocation. Up to the moment that the contract is made, or more accurately, is to take effect, the agent retains both his status as a person and whatever rights that entails, including the right to make a contract. Only after the contract takes effect does the agent (putatively) "cease to be a person" and thereby lose all his rights. Thus if the contract to abdicate autonomy is valid, any further contract that the agent might wish to make is not.

It is not clear why the voluntary slave, who, admittedly, no longer has any rights, thereby also "ceases to be a person." This seems to stem from the definition of the person as a rights bearing entity. But if man has rights, then he has the right to relinquish those rights. If he cannot relinquish them, he did not really (fully) have them in the first place.

But it is important, for Kuflik (1984, p. 282), that the slave no longer be a person. In this way, he cannot benefit from that decision to sell himself into bondage:

To put the point more plainly, when you abdicate autonomy, there is really no "you" left to be the recipient of whatever benefits might be offered in return; and that is why nothing could really repay you for your loss.

But just one sentence later Kuflik (1984, p. 282) is telling us

The agent who agrees to become someone else's complete and permanent slave need not have his own welfare in mind at all; the concession he seeks in return might be a benefit that is to be bestowed upon loved ones or the promotion of a worthy cause.

Whatever happened, in that short space, to "nothing could really repay you for your loss"? Obviously, this is a falsehood. No one would sell himself into slavery, or, indeed, take any kind of human action (Mises, 1949) did he not see in it at least some sort of benefit for himself. Saving a sick child from a certain death would surely qualify under this rubric. And, as for there being no "you" left to the father who does this heroic deed, he is still a human being, albeit no longer a rights bearing one; personhood cannot be banished so easily as rights, for people who are still alive[14].

\subsection{Mill}

Kuflik (1984, p. 283) approvingly cites Mill's (1975 [1859], p. 125) claim that "the person who proposes to sell himself into slavery would "defeat" by this one act the "very purpose which is the justification" for allowing him to dispose of his own lot in life." For Mill of course, and now, presumably, Kuflik, the reason men have rights is to promote utilitarianism[15]. Assume this, for argument's sake, to be correct. However, even Kuflik (1984, p. 282) himself has just admitted that a person's sale of himself into slavery "might be a benefit that is to be bestowed upon loved ones or the promotion of a worthy cause." Is this not utilitarian? 


\section{Two objections}

\subsection{Ordered to commit evil deed}

In the next section of his paper, Kuflik deals with two objections to his inalienability thesis. First, he (1984, p. 286) makes the case against voluntary slavery as follows:

... suppose that once the agreement has taken effect, the agent is ordered to commit an extremely evil deed - for example, to murder another man's wife and children. Now the agreement to abdicate autonomy is an agreement to become the mere tool of someone else's will. If it is valid, then the autonomy abdicating agent has no right to object, let alone to refuse. He has only an unbounded, unconditional duty of obedience.

This is particularly telling, since the person who sells himself into slavery, we have posited, has done this to save his own (wife and) children. Kuflik might have even elevated his example into a truly horror scenario, by offering the scenario where the master commands his slave to kill his own family, precisely the people he was attempting to save by abdicating his autonomy.

Kuflik (1984, p. 287) quite correctly sees the possibility of a "more limited and conditional authority" passing from the autonomy abdicator to the slave owner; a sort of prenuptial agreement for the slave contract. But even if this is not negotiated beforehand, the Kuflik horror scenario makes little sense, for, as he himself (1984, p. 277) has cited in Locke, (1960, sec 135): "For nobody can transfer to another more power than he has in himself." Since the autonomy abdicator had no right to kill either his own family or that of another, he cannot transfer this right to his new master. Not having done that, the latter has no right to command that his slave perpetrate this evil deed. This obviates Barnett's $(1986,1998)$ charge that there is a logical contradiction inherent in the voluntary slave contract between the rights of the innocent family and the duty to obey the slave owner in all things[16].

But suppose that the slave master, even though he has no right to do so, orders his slave to kill his own (or some other innocent) family in any case. We may assume that this is attained through the use of "... a measure of "mind control" (which) can be attained through psychosurgery, brainwashing techniques, mind altering drugs, and the like" (Kuflik, 1984, p. 281). In this case, the slave, presumably, is not in any worse position than he would have been had he not sold himself into slavery, since his family would have died in any case from the illness which was cured thanks to the funds derived from the sale price. Now suppose that the slave is ordered to kill someone else's equally innocent family. Again, it is unlikely that this family, either, is in a worse position than would otherwise have obtained, since any slave master who gives the order to kill innocent people to his slave would probably have either done the evil deed himself, or found others (Murder, Inc.) to do so, or used "compulsion or duress" (Kuflik, 1984, p. 275).

But we are digressing from the logic of the law to mere utilitarian considerations, and it is time to revert back to pure philosophy. The point, here, is that Kuflik has not shown any invalidity to the sale of autonomy abdication. Even if there are additional deaths (which remains to be shown) there is no contradiction, since, thanks to Locke we know that it was legally incorrect to order the slave to engage in these murders.

Conceivably, however, Kuflik has shown that voluntary slave contracts might be unwise. If, after all, the master can take back, after enslavement, what he gave to his slave (money for the security of his family), this is hardly of benefit to the seller. But this does not at all impugn the legitimacy of the deal[17].
Alienability: rejoinder to Kuflik 
$\mathrm{H}$

23,3

124

One should not equate voluntary slave contracts with total abdication of the will. Some voluntary slave contracts might, conceivably, call for this. But others might not. That is, they might be limited to setting up a legal right for the master to commit assault and battery upon the slave under certain conditions. Here, the slave would retain his will, or autonomy, and only yield his legal right to object to being physically brutalized. The voluntary slave contract is still not rendered logically contradictory.

Kuflik (1984, pp. 288-289) asks us to consider

... the case of an agreement to abdicate autonomy ... if that agreement is valid, then the agent simply has no right to function as a critically reflective moral agent. In abdicating autonomy he alienates the right to weigh the evil of doing something he has been ordered to do against the evil of not observing the terms of the agreement. Thus, someone who is judiciously engaged in a careful consideration of reasons for and against the course of conduct he has been ordered to take is already operating outside the bounds of an agreement to abdicate autonomy.

There are two possible replies to this sally. First, the owner and slave can sign a "prenuptial" agreement, limiting the power of the former to use the latter as a vehicle for illegitimate behavior. This would still justify the institution of voluntary slavery, albeit for a somewhat limited variety[18]. Second, we continue to insist that the master has no right to order rights violative behavior, since the autonomy abdicator never owned the right to do anything of the sort, and hence could not sell it to his new owner. As well, the slave is in no worse position than the kidnap victim.

\subsection{Protect against one's irrational self}

Now Kuflik (1984, pp. 291-2) arrives at the second major objection to his inalienability thesis, "self imposed paternalism": autonomy abdication in order to protect against self acknowledged irrationality. He states:

...the agent relinquishes the right to have the guardian's authority revoked...his authorization is tantamount to an abdication of moral autonomy, but could the decision to enter into such an arrangement bear the weight of morally rational self scrutiny?

For Kuflik (1984, p. 292), "rationality" is the criterion of interest, along with whether or not an act of autonomy abdication is "unreasonable" or "irresponsible." For me, in contrast, the issue is whether or not such acts are just, e.g. are non-rights violative; in other words, I ask whether the court in a free society should enforce such a contract. I argue, in contrast to $\operatorname{Kuflik}(1984$, p. 292) that “ . . . an irrevocable guardianship arrangement draws its legitimacy from the fact that the agent himself opted for it" along with the assumption that someone, for consideration, agreed to take it on. Whether it is "rational" or not is a completely separate and irrelevant issue.

This is similar to the case of the sailor in the Greek myth who ties himself to his ship, so that he will not be tempted by non-existent female goddesses in the future. Only instead of the chain, there is the guardian. The benefit of the chain is that while under the influence of the goddesses, this piece of equipment will not yield to the sailors (temporary, irrational) change of mind [on this see Anderson and Block (1995)]. But what good is a guardian who will relinquish his power, just when he is needed? Of course it must be a non-relinquishable guardianship, if it is to accomplish the good it was set up to do. 
Comments Kuflik (1984, p. 292):

... anyone who consented to such an arrangement (agreeing to non-relinquish able ward status) would thereby exhibit a level of incompetence that deprived his "consent" of morally binding force.

But this is no more than naked raw paternalism. There is a right to be irresponsible, unreasonable, with your own property, and your life and liberty which are, at least in the libertarian view, owned by yourself. If by law you cannot give them up, then, and to that extent, you do not really own them. Were Kuflik's philosophy in charge of the boat, the sailor in the Greek myth would not only not be free to take on a non-relinquishable guardianship arrangement, he might not even be able to chain himself to the mast to ward off future temptation, if "Captain" Kuflik thought this irrational.

Kuflik (1984, p. 293, no. 21) states:

... to say that a person has no right to contract away his autonomy is not to deny that in the event of his total demise as a rationally self managing moral agent, his previously expressed wishes should carry at least some weight in the selection of a suitable guardian (emphasis added).

Kuflik is intent on denying that mere consent of the agent himself is sufficient to abdicate autonomy to a guardian. By allowing the agent's wishes to have "some weight" in the decision over a guardian this author implies that other people, other, that is, than the agent himself, should also have a say in making this determination. Take the following example: an old man on his deathbed arranges with his eldest son for the latter to be his guardian; he does this on a non-revocable basis, because he trusts his son to care for him, more than he trusts his (future) self with this task. Kuflik the legislator will not allow this. For him, this is illicit irrational and irresponsible abdication of autonomy. While "some weight" should be given to this decision, it should not be considered definitive. The obvious question is, who else beside the old man should have decision making power in the choice of a guardian? There is a further implication of the phrase "carry at least some weight." It is that if this other person, say a bureaucrat social worker appointed by the state, should disagree with the wishes of the old man to engage his son, the views of the former should prevail. The old man, then, should get only a minority say in his own fate, according to Kuflik. But by what right does the all loving government (or anyone else) poke its nose into this essentially private arrangement?

Kuflik does not seem to appreciate that the person who fears his future irrationality at the present moment full well realizes that at this later date he will no longer wish to be under the domination of the guardian. It is for precisely this reason that he now, while still rational, wishes to have his later decisions abrogated. But paternalist Kuflik (1984, p. 294) is having none of this:

Nor does someone abdicate autonomy when, believing that he may lose even his highest order capacity for morally rational reflection, he calls upon others to be particularly alert to that possibility and to be prepared if his fears should come true, to act appropriately.

What reason does Kuflik (1984, p. 295) give for legally prohibiting non-relinquishable guardianship contracts? On the assumption that the:

... individual remains capable of functioning as a critically reflective moral agent... then any purpose which might have warranted his authorization as a guardian is ill served by his prior renunciation of the right to have the guardian's authority revoked (emphasis added).
Alienability: rejoinder to Kuflik 
$\mathrm{H}$

23,3

126

They may well be the case. But to characterize a contract as unwise is totally irrelevant to the important issue of whether or not it should be legal. There are many unwise business decisions being made in the stock market every day. Should they be prohibited by law since they "ill serve" people who zigged when they should have zagged?

Kuflik (1984, p. 295) continues:

... a condition of the possibility of legitimately placing a person under a guardianship authority which he has no right to revoke is that he be incapable of functioning as a rationally self accountable moral agent. (In Kant's phrase, he has "ceased to be a person.") ... Thus Kant was right in thinking that there is something absurd in the idea of a person legitimating his own total subordination to another person's will by a mere contract.

But this is problematic. First of all, whether something is "absurd" or not is beside the point. The issue is whether or not the courts should accept such agreements as valid and binding. Some styles of clothing may also be "absurd," but judges do not and should not repeal laws against stealing them[19]. Secondly, if a "mere contract" will not succeed in achieving a non revocable guardianship, then what, pray tell, will? Surely there is no better demonstration of a person's will than that he agreed to something, no matter how imperfect or "absurd" it might be considered by third parties such as Kuflik[20].

Kuflik (1984, pp. 295-6) claims that "The right to function as a rationally self accountable moral agent . . . cannot be legitimately abdicated." But this conclusion does not follow from the premises of his argument. There, he showed only that such contracts might be "absurd," and might "ill serve" those who rely upon them, but even were these claims true, they do not even touch upon legal legitimacy.

It is more than passing curious that after having spent an entire article denying that people can give up their autonomy voluntarily[21], Kuflik (1984, pp. 296-8) then embraces a democratic form of government, which implies that people can be forced to alienate their will (to a majority of their fellows) against their own will. This is because, under democracy, the majority "rules." This means that the minority is forced to give up rights not volitionally, as under voluntary slavery, but through force[22]. Kuflik (1984, p. 297) goes so far as to say that "nobody has the right to be a dictator," without realizing that under the democratic system he favors, all those in the majority are indeed "dictators"[23].

The point is, full autonomy leads necessarily to philosophical anarchism, Kuflik (1984, p. 298) notwithstanding. Were Kuflik consistent with his own principles, far from relying on a non-existent social contract to buttress his yearning for democracy, he would criticize it as an abdication of autonomy. It is only the position being adumbrated in this paper, that one has a right to do with his autonomy exactly as he wishes, that is consistent with a social contract. Kuflik may not, upon pain of self contradiction, proclaim himself an advocate of the state, even one agreed to on a unanimous basis, without rescinding his views on alienability. For to agree to a social contract is to put one's fate into the hands of other people, a master, e.g. a majority. If Kuflik objects to renouncing autonomy in favor of a master, why does this not apply to a whole group of "masters," namely, the majority vote on any particular issue? If Kuflik fears that the master will order the slave to kill people, why does he not express this fear with regard to the majority? Nazi Germany, after all, was a democracy, at least in its inception. Hitler ordered the killing of innocents, on a massive scale. Based on the 
doctrine that a person cannot alienate his will, the minority of Germans who disagreed with the Nazi agenda were in effect slaves.

\section{The utilitarian logic of inalienable rights}

\subsection{Subsistence}

Now consider Kuflik (1986) who offers another spate of arguments opposing human alienability. He (1986, p. 80) begins as follows:

It is always possible, of course, to imagine conditions of very great economic hardship under which some people, in the hope of being maintained at subsistence level, might be willing to sign an agreement to become slaves.

But this is unconvincing as an explanation for voluntary slavery. For the marginal revenue productivity of slaves is always below that of free men. For one thing, the slaves were caught, the free men were not; this is evidence of greater ability on the part of the latter; but is only a presumption, not a necessity[24]. A second consideration is also empirical. The master has to spend money to guard slaves, lest they run away, which need not be done for free employees. This also suggests, but does not require, that slaves are less productive than free employees, when such guarding costs are incorporated into the analysis, e.g. subtracted from their gross output. But a third consideration is definitive, necessary, and hence praxeological. If there were a situation of literal subsistence levels of income, then the present discounted value of owning a slave would be zero. For, by definition, a subsistence level means that the typical worker cannot produce more than the amount needed to feed and cloth himself and enough of a family to ensure replacement. But if he cannot produce at a higher level than this, there will be no present and future profits to discount. This being the case, no potential master would be willing to purchase such a slave at any positive price. Why would anyone want to buy a human being unable to produce more than that amount necessary to feed, cloth, and replace himself? Far from encouraging or explaining such a system as per Kuflik, this state of affairs would spell the death knell for slavery.

\subsection{Right to vote}

Kuflik's (1986, p. 83) next swipe at alienation concerns the right to vote: "If there is good reason for a democratic political process, then there is good reason...for the inalienability of the right to vote."

Even granting that democracy is justified[25], it by no means follows that alienability should be proscribed. There are numerous instances of democracy which have functioned for decades which allow vote buying and selling: to wit, the market for shares in business firms. An economic democracy[26] of sorts prevails within the confines of all modern corporations. Shares in the company, e.g. votes, may be legally traded.

Look at it again from the point of view of the citizen of a country, continuing with our assumption that democracy is a viable system. In the fully free society[27], each member of the electorate would be able to sell his vote, or buy that from another, at any agreeable terms of trade. From our knowledge of basic economics we know that all such commercial arrangements are positive sum games, at least in the ex ante sense. That is, every sale and purchase takes place because each party to the trade values that which he receives more than what he gives up, otherwise the deal would hardly take place.

Alienability: rejoinder to Kuflik 
$\mathrm{H}$

23,3

128

Of course, under this system, the wishes of the more well to do would be heard more loudly than under one, other things equal, where vote selling was prohibited or impossible. But the poor, or those less interested in the political process as we have seen, will have demonstrated[28] by their participation that they too benefit.

\subsection{Housing standards}

Another critique offered by Kuflik (1986, p. 83) has to do with minimum quality standards for housing:

Consider, in this connection, a right only recently afforded the status of legal inalienability the tenant's right to the minimum habitability of his rented domicile... the state can simply refuse to uphold any agreement by which a tenant "alienates" the right to be provided with a minimally habitable domicile.

Suppose that in the absence of any external coercion from the state, a poor person rents a very low quality "Geo" apartment for $\$ 100$. Now, the government steps into the picture, abrogates that rental agreement, and forces the poverty stricken man into a higher quality "Camry" dwelling for $\$ 200$. Why are we entitled to conclude that the man's welfare has been raised? Things are very much the opposite. After all, the rental authority has merely taken away one option previously available to the poor: the ability to pay a cut rate price for low quality real estate. We do the poverty stricken no favor by forcing them into a commercial arrangement they have already rejected[29] in favor of one we impose upon them.

Unless, of course, paternalism is justified. But this option is not open to Kuflik, who is on record as favoring democracy. Paternalism and democracy are of course antithetical. The one says that the average man on the street is incapable of picking an apartment for himself. The other claims he is worthy of the ballot box vote. That the two are difficult to reconcile is a vast understatement.

\subsection{Freedom of choice}

Kuflik's next foray in favor of inalienability is on consequentialist grounds; e.g. preserving freedom of choice. He states (1986, p. 85):

... a binding agreement to serve as a slave (or to be married in perpetuity, regardless of cruelty, infidelity, etc.) has an indefinitely large potential for destroying a person's peace of mind and undermining his fundamental sense of well being.

There are several difficulties here. It is all well and good to say that non-perpetual marriages (e.g. easy divorce laws) "preserve freedom of choice." Certainly they do; that is, the freedom to leave the marital state. But what about "preserving freedom of choice" to engage in a fully binding marriage? This, it would appear, gets cut off at the knees by Kuflik. Similarly, "... a binding agreement to serve as a slave" certainly reduces options after that fact. But to preclude such a contract is to diminish choice beforehand. So far, it is not at all clear that inalienability reduces alternatives[30].

Actually, the case is worse for Kuflik in this regard. For the bride and groom who agree to marriage until death do them part, and the voluntary slave, realize full well that their future decision making power will be reduced after they embark on these respective agreements. Yet, they accept this package deal of choice now, limitations thereafter. These options, then, are not so much a decline in freedom as an exercise of it[31]. 
When I buy a newspaper for $\$ 1$, I also limit my freedom of choice. After all, there are many more people willing to take eight bitts off my hands than today's paper. Also, I no longer have that dollar with which to buy something else. Would Kuflik prohibit the sale of the daily paper on this ground?

An even greater objection to Kuflik $(1986$, p. 85) is provided for us courtesy of Kuflik (1984, p. 290):

It is sometimes said that an agreement to abdicate autonomy is, in principle, no different from other agreements; any agreement will tie down the agent's future in ways that limit liberty and narrow his options. But the line of argument presented here does not turn on the proposition that we must always try to leave our options open, or on the (dubious) claim that we must never undertake irreversible enterprises. Any course of conduct ... inevitably closes off options that would have been open otherwise.

The Kuflik of 1986 stands refuted by the Kuflik of 1984.

\subsection{Well being}

A similar analysis applies to the issues of "peace of mind and ... fundamental sense of well being." Why does Kuflik suppose that the husband and wife and the slave are making their respective choices apart from an attempt to promote their own "peace of mind and ... fundamental sense of well being?" On what ground does this author deny they will attain it? Or, even given that they will not attain their goals, that they should be prevented by law from even trying? Does not Kuflik himself ever fail to reach his ends? Does this mean we are entitled to stop him from making such attempts? Hardly.

As far as "preserving freedom of choice" and securing "peace of mind and ... fundamental sense of well being" are concerned, moreover, it does not seem to have occurred to Kuflik that being able to dispose of your property as you wish, or save your children's lives, or enter into any kind of marriage contract you wish, is highly conducive toward these aspirations. This is part and parcel of what we mean by freedom: the ability to obtain something now, even if by so doing one reduces one's scope of activity later.

\subsection{Fraud}

In another stab at this concept, Kuflik notes that making rights inalienable can remove an incentive to fraud[32]. He states (1986, p. 85):

... if the right not to be battered were inalienable, relatively few masochists would be deprived of the enjoyment they seek.... it is reasonable to infer that the suffering of the relatively few individuals who would be deprived of sadomasochistic enjoyment under an inalienability policy would not be nearly as great as the suffering of the many more persons who, under the policy of recognizing the "consent" of the victim as a defense, would be fraudulently added to the ranks of the battered.

Another difficulty is that by placing quotation marks around the word "consent," Kuflik is arguing in effect that he doesn't really think that the masochist is giving consent; he is in effect deluded, or confused, or some such. But the reasons for such a claim are irrelevant to this charge. Rather, they make a very different, and utilitarian point: if we steadfastly refuse to recognize the very real consent the masochist gives to his sadist[33], we can solve a few additional crimes of assault and battery, or even prevent them from occurring in the first place. This may well be true. And if so, why not leave off this promiscuous use of quotation marks, and at least admit that the policy is an unjust one, in that it violates the rights of masochists? And not only people

\section{Alienability: rejoinder to Kuflik}


$\mathrm{H}$

23,3

130 who hire others to beat them up. What about those who engage in boxing? wrestling? karate? judo? These people all bear the risks of direct physical attack[34]. And then there are those who willingly accept risk to life and limb such as coal miners, policemen, firemen, test pilots, lumberjacks, soldiers, race car drivers, etc. All of this is a form of what might be called "semi masochism."[35]. We cannot be sure that these people really "consent" to be members of their professions, if this author is correct.

Kuflik (1986, p. 86, no. 5) specifically exempts from his rule medical operations and boxing matches, which might be considered as consensual battery. The former, he claims, "is closely related to the rationale for prohibiting battery in the normal case namely, preservation of human health and well being." But this is not at all the reason why the law proscribes battery. It does so, rather, because this crime is an invasion, in utter disregard of its utilitarian detriments. Posit the opposite to be true; that is, suppose battery as beneficial, in much the same way as is, for example, body massage. No matter how beneficial, was a masseur to force his services on unwilling clients, he would and should still be found guilty of violating the law[36].

Kuflik's reason for exempting boxing is that "the primary objective is not to be battered but to earn fame or fortune." But surely the former, not the latter, is the motive of at least some boxers. It would appear, if we could cheaply distinguish these from the others, that their participation in this sport would have to be prohibited. Why, in any case, should mere motive determine whether an act is legal or not? The problem is, the mere fact of stepping into the ring puts your life in danger. One (good) punch can do it, and this can occur at any time.

Further, if we are to entrench into the law the idea that rights may be violated with impunity in order to reduce crime, the opens up a Pandora's Box of preventive detention. If all black males were arrested at age 13 , and released at age 29 , the crime rate would take a nosedive. Is Kuflik suggesting such a rights violative policy? If not, why not?

As a matter of technical economics, moreover, it is not at all "reasonable to infer" that the suffering of one group, masochists, "would not be nearly as great as" the suffering of another, those victimized by assault and battery. Sufferings of this sort simply cannot be compared on a scientific basis. Pain cannot be measured. To say that we lack only the means to make such comparisons is to imply that one day, there will be a machine which can measure (un)happiness. The problem is more basic than that. There are no units of (un)happiness for the machine to measure[37].

\subsection{Bargaining power}

Kuflik (1986, p. 86) launches another critique at alienability based upon achieving a socially more desirable balance of bargaining power[38]. In his view:

If the right to sue for divorce were legally alienable ... some of these people (those with strong bargaining power in the marriage market) would be tempted to take advantage of the existence of the alienation option and of the relatively weaker "bargaining" position of their more marriage minded partner, to demand that the other person make such a concession .... in not having the right to alienate a right, a person is no longer vulnerable to the demand that he alienate it.

There are several problems here. Why should it be any outsider's business, let alone be "socially more desirable," that rich men and beautiful women no longer be able to have more of their way in romantic relationships vis-a-vis their poorer and plainer counterparts? If anything, the extant situation is better suited for Kuflik's (1986, p. 86, 
no. 5) "preservation of human health and well being." This is because there are good sociobiological rationales for the present state of affairs, which inures to the benefit of the human race[39].

Even stipulating that public policy requires a righting of the imbalance between the beautiful people and their less fortunate brethren and sistern, the evidence is unclear that inalienability will attain this goal. Kuflik (1986, p. 79) desires a situation where "...no agreement relinquishing the right to sue for divorce would be valid and binding." But even if he attains it, his scenario may well be swamped by the opposite effect: those with strong sexual bargaining power will not marry those with less in the first place. It is thus not at all clear that weaker bargainers in the marriage market would improve their position. It is certainly not clear that they should.

\section{Conclusion}

Liberty is a seamless web of interconnected rights. Kuflik has attempted to deny the right of people to sell themselves, to make contracts which subsequently restrict their range of options. In so doing, he has had to ignore or trample on a whole host of other related rights. His case against free enterprise and the rights of individuals to do with their freedom precisely as they wish (provided they respect the equal liberties of all others) has not been made.

\section{Notes}

1. The minority, pro total alienability side of this dispute, apart from the present essay, consists of the following: Nozick (1974, p. 331, no. 48), Block (1999, 2001, 2002, 2003, 2006).

2. Incomplete alienability or commodificationism.

3. Kuflik (1984, p. 271, no. 1) notes that Locke (1960), Spinoza (1951), Rousseau (1968), and Kant (1930) all agree: the will cannot be alienated. In contrast, Nozick (1974, p. 331, no. 48) and Block (1999, 2001, 2002, 2003, forthcoming) deny this.

4. With apologies to Ivory Soap. See http://en.wikipedia.org/wiki/Ivory_(soap)

5. This concession contradicts the views of Rothbard (1998[1982]), Barnett $(1986,1998)$, Gordon (1999), Smith (1996), Kinsella (1998-1999), and Epstein (1985). These writers maintain it is impossible to relinquish autonomy. For a critique of their views, see Block (2003).

6. And this is for some unspecified reason intolerable.

7. I assume if only for argument's sake, that this concept is a coherent one. For an alternative view, see Szasz $(1961,1963)$.

8. See below for Kuflik's treatment of this charge.

9. Kuflik (1984, p. 279) cites Kant (1970, p. 76): “... no legal transaction on his part or on that of anyone else can make him cease to be his own master." But this would preclude guardianship. How can Kuflik take comfort from this?

10. Or, in favor of, if you will.

11. I mean this not as a critique of men of religion; rather, of Kuflik, who gratuitously dismisses some quite reflective people by placing so great an emphasis on thinking for yourself, relying on no one else. For him, it might be said that the phrase from the TV show X Files ("trust no one") is a personal motto.

12. Kuflik's (1984, p. 276) view, “... suppose a person agrees to do what someone else tells him to do. If in making the agreement he agrees never to deploy his own critically reflective moral judgment, then ... he has clearly abdicated... his autonomy.” Also,

\section{Alienability: rejoinder to Kuflik}


$\mathrm{H}$

23,3

\section{2}

Kuflik (1984, p. 281): “. . even if someone were perfectly capable of complying with an agreement to abdicate autonomy, he would still be wrong to make it." But if I am wrong in doing something, e.g., stealing, this logically implies that I actually carried out this crime. If it is wrong to abdicate autonomy (Kuflik is in error on this point, but let it pass), it certainly follows that it can be done.

In yet another contradiction of himself, Kuflik (1984, p. 285) states “... insofar as the agent's decision is rationally defensible, it is not actually a decision to abdicate autonomy; insofar as it is a decision to abdicate autonomy, it is demonstrably irrational."

13. Kinsella (1998-1999) has characterized this as "zombicide."

14. The Nazis and Communists succeeded in the latter task, not the former.

15. For a blistering attack on utilitarianism, see Rothbard (1998 [1982]).

16. For a reply to Barnett $(1986,1998)$, see Block (2003).

17. Gordon (1999) points out that while this might be unwise, it does not invalidate the contract.

18. For example, the master could not ask his voluntary slave to be an overseer (e.g. whipper) for other slaves who came to him not through contract but via coercion.

19. Similarly in the case of rap "music."

20. This reliance upon contractual agreement should not be construed as an elevation of contracts to a position of total eminence in legal philosophy. For the argument that property rights are logically prior to contracts, see Hoppe et al. (1998).

21. Albeit with reservations, as noted.

22. Of course, if there was a social contract agreed to unanimously, on the basis of which the democratic vote took place, then there is no coercion of the minority, since these people agreed to be bound by democratic vote. One problem is, even if there was consent, still, this allows Kuflik to escape only from the fire of coercive slavery into the frying pay of voluntary slavery. In the real world, however, Kuflik cannot escape from the fire to the frying pay for there is no unanimous agreement to the rules of the game. On this see McGee (1991, 1992), Spooner (1966 [1870]), Rothbard (1965, 1970, 1977a,b, 1978, 1998[1982]), Hoppe (1989, 1993), De Jasay (1985), Benson (1990), Barnett (1998), Tinsley (1998-1999), and Stringham (1998-1999). The libertarian escapes this dilemma since his only axiom, non-invasion of innocent parties and their property, can be "imposed" on all people without violating their rights, since they have no "right" to invade in the first place.

23. Unless, of course, they restrict their rulings to the upholding of the libertarian axiom of non-aggression.

24. Strictly speaking of course, this applies only to slaves who are captured, not purchased from themselves, as sellers. It is of crucial importance to distinguish between the voluntary slave contracts being defended in this essay, and coercive slavery as practiced, say, in the pre-Civil War US south, which most certainly is not being advocated. For an analysis of this historical epoch, see Hummel (1996).

25. We are accustomed to giving lip service approval to democracy. But Hitler came to power through a democratic process, which should give us at least a bit of pause for thought. For a thorough going critique of this thesis, see Hoppe (1994).

26. Very far removed, of course, from that advocated by California Representative Tom Hayden, and his Committee for Economic Democracy.

27. We pass over the issue of whether these two systems, democracy, and free enterprise, are logically compatible.

28. For further elaboration on this Rothbard (1977). 
29. They always had the option of the Camry dwelling, at a higher rent. Yet, by stipulation, they rejected that in favor of the cheaper Geo quarters. This shows they prefer the latter to the former. How is forcing them into the former, instead of the latter, a help to them?

30. Kronman (1983, pp. 775-6) states: "One can argue, as Mill does, that without such a prohibition... (against self enslavement) ... the right to self control may be destroyed through its alienation and conclude that a bar against self-enslavement is necessary to preserve the desired distributional pattern of personal liberty. But this begs the question: Why does a person's inability to enslave himself increase his self control rather than diminish it. Any theory of distributive justice that purports to explain the prohibition against self-enslavement assumes the answer to this question, an answer that cannot be supplied by the theory itself."

31. States Kuflik (1986, p. 81): “... there does seem to be something appealing about the policy of permitting somebody who has legitimate grounds for divorce (e.g., cruelty, infidelity, etc.) and who wishes to file for divorce to go ahead and do so, regardless of any "agreement" to the contrary." This author is of course correct that there is something "appealing" about contract abrogation. The party to the deal who regrets his decision will always find contract violation "appealing." Recently, I sold a few shares of stock which increased in value the very next day. I regretted this decision. As an investor anxious to maximize his return I would find it "appealing" if the authorities would give me back these shares (I would gladly return the proceeds I received at the lower price) which are now worth much more. As a matter of law and political economy, however, this suggestion is appalling. No less than our entire economy rests on all of us being forced to live up to the specifications of contracts we sign.

32. For a similar argument, see Barnett (1986, p. 193). For a critique, see Block (2003).

33. See the Dirty Harry movie where the bad guy submits to a voluntary beating in order to get our hero into trouble.

34. Not of course the fake wrestlers; rather, the real ones.

35. The ultimate in masochism is "murder park." Here, the manager of this private enterprise gives you a pistol and six bullets, and tells you that the rules of his establishment is that you are free to shoot any other patron for the next 50 minutes. During the last ten minutes of every hour is held a "no shoot" time period during which ammunition is replenished, new customers are introduced into the proceedings, old ones are allowed to leave in safety, and the dead and wounded are carted away. The walls are 20 feet thick, and all participation is on a voluntary basis. Surely such an emporium would be legal in a fully free society.

36. Suppose I break into your house and steal your TV? Clearly this is, and should be, against the law. But there need not be any diminution to "human... and well being." For example, your insurance company may pay you more than the TV was worth to you. And, thanks to my invasion, you may install a better security system, which will protect you from a robber, scheduled to arrive at your domicile in a month, who would have killed you. The negative utilitarian effects upon me, the thief, may be ignored on the assumption that I die soon after, without setting any precedent for future such behavior (I owe this example to Tibor Machan.).

37. Economists have gone so far as to label these non-existent units "utils." But this only shows, contrary to accepted folk wisdom, that dismal scientists have a great sense of humor. Yes, we all know that person A likes peanut butter, $\mathrm{B}$ hates it, and $\mathrm{C}$ is indifferent. We may even take a stab at guessing that A savors this foodstuff more than $\mathrm{B}$ disparages it, but these are informal assessments, not suitable for public policy analysis. The point is, we do not have scientific capability to interpersonally compare utility. The posturing of Kuflik, and most economists, to the contrary is therefore invalid. See on this Rothbard (1977).

\section{Alienability: rejoinder to Kuflik}


$\mathrm{H}$

23,3

134

38. For other detractors of alienability based on "distributive justice", see Kronman (1983, 770-4) and Rose-Ackerman (1985, p. 940).

39. On this see Axelrod (1984), Barkow et al. (1992), Buss (1994), Dawkins (1976, 1986, 1995), Ridley $(1993,1996)$, and Wilson (1975).

\section{References}

Anderson, G. and Block, W. (1995), "Procrastination and obedience: a reply to akerlof", American Journal of Economics and Sociology, Vol. 54 No. 2, pp. 201-15

Axelrod, R. (1984), The Evolution of Cooperation, Basic Books (Harper Collins Publishers), New York, NY.

Barkow, J.H., Cosmides, L. and Tooby, J. (Eds), (1992), The Adapted Mind: Evolutionary Psychology and the Generation of Culture, Oxford University Press, Oxford.

Barnett, R.E. (1986), "Contract remedies and inalienable rights", Social Philosophy and Policy, Vol. 4 No. 1, pp. 179-202.

Barnett, R.E. (1998), The Structure of Liberty: Justice and the Rule of Law, Clarendon Press, Oxford.

Benson, B.L. (1990), The Enterprise of Law: Justice Without the State, Pacific Research Institute for Public Policy, San Francisco, CA.

Block, W. (1999), "Market inalienability once again: reply to radin”, Thomas Jefferson Law Journal, Vol. 22 No. 1, pp. 37-88.

Block, W. (2001), "Alienability, inalienability, paternalism and the law: reply to Kronman", American Journal of Criminal Law, Vol. 28 No. 3, Summer, pp. 351-71, available at: www.walterblock.com/publication/reply_to_kronman.pdf

Block, W. (2002), "A critique of the legal and philosophical case for rent control", Journal of Business Ethics, Vol. 40, pp. 75-90, available at: www.mises.org/etexts/rentcontrol.pdf

Block, W. (2003), "Toward a libertarian theory of inalienability: a critique of Rothbard, Barnett, Gordon, Smith, Kinsella and Epstein”, Journal of Libertarian Studies, Vol. 17 No. 2, Spring, pp. 39-85, available at: www.mises.org/journals/jls/17_2/17_2_3.pdf

Block, W. (2006), "Epstein on alienation: a rejoinder”, International Journal of Social Economics, Vol. 33 No. 3, pp. 241-60, available at: www.emeraldinsight.com/Insight/viewContainer.do? containerType $=$ Issue\&containerId $=23531$

Buss, D.M. (1994), The Evolution of Desire: Strategies of Human Mating, Basic Books, New York, NY.

Calabresi, G. and Melamed, D. (1972), "Property rules, liability rules, and inalienability: one view of the cathedral”, Harvard Law Review, Vol. 85 No. 6, April, pp. 1089-1128.

Dawkins, R. (1976), The Selfish Gene, Oxford University Press, New York, NY.

Dawkins, R. (1986), The Blind Watchmaker, Norton, New York, NY.

Dawkins, R. (1995), River Out of Eden, Basic Books, New York, NY.

De Jasay, A. (1985), The State, Basil Blackwell, Oxford.

Epstein, R. (1985), “Why restrain alienation”, Columbia Law Review, Vol. 85, p. 970.

Feinberg, J. (1978), "Voluntary euthanasia and the inalienable right to life", Philosophy and Public Affairs, Vol. 7, p. 117.

Gordon, D. (1999), "Private property's philosopher”, The Mises Review, Vol. 5 No. 1, pp. 1-7.

Hoppe, H.-H. (1989), A Theory of Socialism and Capitalism: Economics, Politics and Ethics, Kluwer, Boston, MA.

Hoppe, H.-H. (1993), The Economics and Ethics of Private Property: Studies in Political Economy and Philosophy, Kluwer, Boston, MA. 
Hoppe, H.-H. (1994), "Time preference, government, and the process of decivilization - from monarchy to democracy", Journal Des Economistes Et Des Etudes Humaines, Vol. 5, p. 319.

Hoppe, H.-H. Hulsmann, G. and Block, W. (1998), "Against fiduciary media”, Review of Austrian Economics, Vol. 1 No. 1, pp. 19-50.

Hummel, J. (1996), Emancipating Slaves, Enslaving Free Men: A History of the American Civil War, Open Court, LaSalle, IL.

Kant, I. (1930), Lectures on Ethics, (L. Infield, trans., and J. Macmurray, rev. Ed.) Cambridge University Press, Cambridge.

Kant, I. (1970), "Theory and practice II; The metaphysics of morals: introduction", sec. B; "The theory of right" Pt. II, sec. 49, D, in Reiss, H. (Ed.) (translated by Nisbet, H.B.), Kant's Political Writings, Cambridge University Press, Cambridge.

Kinsella, N.S. (1998-1999), "Inalienability and punishment: a reply to George Smith", Journal of Libertarian Studies, Vol. 14 No. 1, pp. 79-93.

Kronman, A.T. (1983), "Paternalism and the law of contracts", Yale Law Journal, Vol. 92, pp. $763-98$.

Kuflik, A., (1984), "The inalienability of autonomy", Philosophy and Public Affairs, Vol. 13 No. 4, pp. 271-98.

Kuflik, A. (1986), "The utilitarian logic of inalienable rights", Ethics, Vol. 97, October, pp. 75-87.

Locke, J. (1960), Second Treatise, in Two Treatises of Government Cambridge University Press, Cambridge.

McConnell, T. (1984), "The nature and basis of inalienable rights", Law and Philosophy, Vol. 3 No. 1, pp. 25-59.

McConnell, T. (1996), "The inalienable right of conscience: a madisonian argument", Social Theory and Practice, Vol. 22 No. 3, pp. 397-416.

McGee, R. (1991), “A theory of secession for emerging democracies”, The Asian Economic Review, Vol. 33 No. 2, pp. 245-65.

McGee, R., (1992), "The theory of secession and emerging democracies: a constitutional solution", Stanford Journal of International Law, Vol. 28 No. 2, pp. 451-76.

Meyers, D.T. (1981), "The rationale for inalienable rights in moral systems", Social Theory and Practice, Vol. 7 No. 2, pp. 127-43.

Mill, J.S. (1975 [1859]), On Liberty, Bobbs-Merrill, Indianapolis, IN.

Mises, L., (1949), Human Action: The Scholar's Edition, Auburn, Ala.: The Mises Institute, available at: www.mises.org/humanaction.asp

Nozick, R. (1974), Anarchy, State and Utopia, Basic Books, New York, NY.

Radin, M.J. (1987), “Market-inalienability”, Harvard Law Review, Vol. 100 No. 8, pp. 1849-937.

Ridley, M. (1993), The Red Queen, Penguin, New York, NY.

Ridley, M. (1996), The Origins of Virtue, Penguin, New York, NY.

Rose-Ackerman, S. (1985), "Inalienability and the theory of property rights", Columbia Law Review, Vol.85, p. 931.

Rothbard, M.N. (1965), "The anatomy of the state", Rampart Journal, Summer, pp. 1-24. (Reprinted in Tibor, R. Machan Ed.), The Libertarian Alternative, 1974, Nelson-Hall Co., Chicago, pp. 69-93.

Rothbard, M.N. (1970), Power and Market: Government and the Economy, Institute for Humane Studies, Menlo Park, CA.

Rothbard, M.N. (1977a), "Robert Nozick and the immaculate conception of the state", The Journal of Libertarian Studies, Vol. 1 No. 1, pp. 45-58.

Alienability: rejoinder to Kuflik

.


$\mathrm{H}$

23,3

136
Rothbard, M.N. (1977b), "Toward a reconstruction of utility and welfare economics”, Occasional Paper 3, Center for Libertarian Studies, San Francisco, CA.

Rothbard, M.N. (1978), "Society without a state", in Pennock, J.R. and Chapman, J.W. (Eds), Anarchism: Nomos XIX, NYU Press, New York, NY, pp. 191-207.

Rothbard, M.N. (1998 [1982]), The Ethics of Liberty, Humanities Press, Atlantic Highlands, NJ.

Rousseau, J.J. (1968), The Social Contract, (translated by Cranston, M.) Penguin, Harmondsworth.

Smith, G. (1997), “A killer's right to life”, Liberty, Vol. 10 No. 2, pp. 46-54.

Spinoza, B.D. (1951), Theologico-Political Treatise, chapters 17, 20; Works of Spinoza, (translated by Elwes, R.H.J.) Dover, New York, NY.

Spooner, L. (1966 [1870]), No Treason: Larkspur, CO.

Stringham, E. (1998-1999), "Market chosen law”, The Journal of Libertarian Studies, Vol. 14 No. 1, pp. 53-78.

Szasz, T.S. (1961), The Myth of Mental Illness; Foundations of a Theory of Personal Conduct, Hoeber-Harper, New York, NY.

Szasz, T.S. (1963), Law, Liberty, and Psychiatry; an Inquiry into the Social uses of Mental Health Practices, Macmillan, New York, NY.

Tinsley, P. (1998-1999), "Private Police: a note”, The Journal of Libertarian Studies, Vol. 14 No. 1, pp. 95-100.

Wilson, E.O. (1975), Sociobiology, Harvard University Press, Cambridge.

Wilson, M. and Daly, M. (1992), "The man who mistook his wife for a chattel", in Barkow, J.H. Cosmides, L. and Tooby, J. (Eds), The Adapted Mind: Evolutionary Psychology and the Generation of Culture, Oxford University Press, Oxford, pp. 289-322.

\section{Further reading}

Rushton, J.P. (1997), Race, Evolution and Behavior: A Life History Perspective, Transaction, New Brunswick, NJ.

\section{Corresponding author}

Walter Block can be contacted at: wblock@loyno.edu

To purchase reprints of this article please e-mail: reprints@emeraldinsight.com Or visit our web site for further details: www.emeraldinsight.com/reprints 
Reproduced with permission of the copyright owner. Further reproduction prohibited without permission. 